\title{
Whole grain food diet slightly reduces cardiovascular risks in obese/overweight adults: a systematic review and meta- analysis
}

Weihao Wang ${ }^{1+}$, Jianan $\mathrm{Li}^{2+}$, Xiaoxi Chen ${ }^{2}$, Miao Yu², Qi Pan ${ }^{1 *}$ and Lixin Guo ${ }^{1 *}$ (D)

\begin{abstract}
Background: The effects of whole grain diet on cardiovascular risks in obese and overweight adults is not well established. Our goal was to conduct a systematic review and meta-analysis on the effect of whole grain diet on cardiovascular risks in obese/overweight adults.
\end{abstract}

Methods: PubMed, Embase and Cochrane were systematically scanned for randomized controlled trials (RCTs), and studies were selected based on certain inclusion and exclusion criteria. The primary outcome was the effectiveness of whole grain food consumption in reducing body weight. The secondary outcomes were the effect of whole grain food consumption on cardiovascular disease (CVD) risk factors including plasma low-density lipoprotein cholesterol (LDL-C), insulin resistance index, blood pressure, body mass index (BMI), C-reactive protein (CRP), and waist circumference in obese/overweight adults.

Results: Our results showed that whole grain consumption was associated with lower body weight (mean difference $(\mathrm{MD})=-0.5,95 \%$ confidence intervals $\left.(\mathrm{Cl})[-0.74,0.25], \mathrm{I}^{2}=35 \%, P<0.0001\right)$ and lower CRP $(\mathrm{MD}=-0.36$, $\left.95 \% \mathrm{Cl}[-0.54,-0.18], \mathrm{I}^{2}=69 \%, \mathrm{P}<0.0001\right)$, compared with the control group. However, there were no significant differences in LDL-C (MD $\left.=-0.08,95 \% \mathrm{Cl}[-0.16,0.00], \mathrm{I}^{2}=27 \%, P=0.05\right)$, waist circumference $(\mathrm{MD}=-0.12,95 \% \mathrm{Cl}$ $\left.[-0.92,0.68], I^{2}=44 \%, P=0.76\right)$, systolic blood pressure (MD $\left.=-0.11,95 \% \mathrm{Cl}[-1.55,1.33], \mathrm{I}^{2}=3 \%, P=0.88\right)$, diastolic blood pressure $\left(\mathrm{MD}=-0.44,95 \% \mathrm{Cl}[-1.44,0.57], \mathrm{I}^{2}=15 \%, P=0.39\right)$, and fasting glucose $(\mathrm{MD}=-0.05,95 \% \mathrm{Cl}[-0.12$, $0.01], I^{2}=31 \%, P=0.11$ ) between the two groups.

Conclusion: This study suggests that whole grain food consumption can slightly reduce body weight and CRP in obese/overweight population.

Keywords: Whole grain food, Cardiovascular risk factors, Overweight adults, Systematic review, Body weight

\section{Background}

Cardiovascular diseases (CVD) remain the leading cause of morbidity and mortality in the world, including in China, wherein it accounts for around one third of all deaths [1]. Overweight and obesity are global health problems, their scope and severity are growing [2], and there is a high demand for a global health care system to

\footnotetext{
* Correspondence: panqi621@126.com; glxwork2016@163.com Weihao Wang and Jianan Li are Co-first authors

${ }^{1}$ Department of Endocrinology, Beijing Hospital, National Center of Gerontology, Institute of Geriatric Medicine, Chinese Academy of Medical Sciences, Beijing, People's Republic of China

Full list of author information is available at the end of the article
}

overcome their outcomes. Overweight and obesity management and diets are core approaches in all clinical practice guidelines for reducing the risk of CVD. Besides, nutritional plans to achieve optimal body weight are important for preventing obesity-related diseases.

Observational studies have shown that increased consumption of whole grain foods was associated with lower incidence of metabolic syndrome [3] and lower mortality rates from CVD [4-7]. In addition, studies have shown that whole grain foods exert beneficial effects on glucose metabolism, obesity, blood pressure, body lipids and inflammatory markers [8-11]. Indeed, whole grain foods

(c) The Author(s). 2020 Open Access This article is distributed under the terms of the Creative Commons Attribution 4.0 International License (http://creativecommons.org/licenses/by/4.0/), which permits unrestricted use, distribution, and reproduction in any medium, provided you give appropriate credit to the original author(s) and the source, provide a link to the Creative Commons license, and indicate if changes were made. The Creative Commons Public Domain Dedication waiver (http://creativecommons.org/publicdomain/zero/1.0/) applies to the data made available in this article, unless otherwise stated. 
are recommended for the prevention of CVD due to their cardioprotective content including dietary fibers, trace minerals, phytoestrogens and antioxidants $[12,13]$. Besides, whole grain foods are thought to ameliorate body weight due to their lower energy density and satiety, compared with refined grain foods [5, 14-19].

Several observational studies demonstrated that high whole grain food consumption is associated with lower BMI [20, 21] and lower long-term weight gain [22, 23]. In contrast, a recent meta-analysis showed that whole grain intake may have a slight beneficial effect on body fat mass, with no significant effect on body weight [9]. Similarly, a recent systematic review pointed to inconsistent evidence between intervention studies on the effect of whole grain food consumption on weight loss, independent of caloric restriction [24]. Hence, the overall conclusion from current studies suggesting that whole grain food consumption can reduce body weight is relatively inconsistent and warrant further investigation. Therefore, we aimed in this study to evaluate the impact of whole grain food consumption on cardiovascular risk factors in overweight and obese patients through the meta-analysis of related randomized controlled trials.

\section{Methods}

\section{Data sources}

The meta-analysis was performed according to the Cochrane Handbook for Systematic Reviews of Interventions and Preferred Reporting Items for Systematic Reviews and Meta-Analyses (PRISMA). Briefly, PubMed, Embase and Cochrane Central Register of Controlled Trials databases were scanned for RCTs without time and race restriction. PubMed was queried using the following advanced search query: $((((((($ obesity) [Abstract] OR obese) [Abstract] OR overweight) [Abstract] OR fat)) [Abstract] OR metabolic syndrome [Abstract])) AND (((randomized controlled trial) [Abstract] OR placebo) [Abstract] OR randomized [Abstract])) AND (((Grain, Whole) [Abstract] OR Grains, Whole) [Abstract] OR Whole Grain) [Abstract] OR Grain Cereal, Whole [Abstract]).

\section{Inclusion and exclusion criteria}

Studies were included if they satisfied the following inclusion criteria: (1) intervention time lasted more than 2 weeks; (2) randomized controlled trial; (3) assessing cardiovascular outcomes in obese/overweight adults (BMI $\geq$ $\left.24 \mathrm{~kg} / \mathrm{m}^{2}\right)$; (4) at least one of the following secondary outcomes were measured: weight, blood pressure, BMI, waist circumference and cholesterol. A study was excluded if: it was not an RCT, a review or a meta-analysis, it was a case report, the study time lasted less than 2 weeks, and the reported information were inadequate.

The following data were extracted from each record by two independent researchers (WWH and LJN): study characteristics (author, publication year, duration of intervention time, sample size), baseline characteristics of patients (age, body weight, waist circumference, BMI, systolic blood pressure (SBP), LDL-C), and cardiovascular risk outcomes including body weight (primary outcome) and other secondary outcomes such as plasma low-density lipoprotein-cholesterol level, insulin resistance index, blood pressure (BP), BMI, CRP, waist circumference .

\section{Assessment of bias}

Assessment of bias was analyzed using the Cochrane Collaboration's tool. The following factors were assessed: random sequence generation (selection bias), allocation concealment (selection bias), blinding of participants and personnel (performance bias), blinding of outcome assessment (detection bias), incomplete outcome data (attrition bias), selective reporting (reporting bias), and other bias. Two independent investigators (CXX and $\mathrm{YM})$ evaluated the bias in the included articles.

\section{Statistical analysis}

Statistical analysis was performed using the Review Manager (Revman). The Odds ratios (OR) and 95\% confidence intervals $(\mathrm{CI})$ were calculated for dichotomous outcomes, while the mean difference (MD) and 95\% CI were calculated for continuous outcomes. A $p$-value less than 0.05 was used as a cutoff for statistical significance. The random effect model was used to generate forest plots. The $\mathrm{I}^{2}$ test was used to assess data heterogeneity, where an $\mathrm{I}^{2}$ more than $50 \%$ indicated highly heterogeneous results. Subgroup analysis was conducted on positive results to investigate the source of heterogeneity.

\section{Results}

\section{The characteristics of included studies}

A total of 995 studies were identified by the two investigators, including 518 articles from PubMed, 145 from Embase, and 332 from Cochrane database. From these studies, 45 relevant studies were selected for detailed evaluation, of which 22 randomized clinical trials were finally included for the meta-analysis. The screening process for eligible studies is shown in Fig. 1. The characteristics of studies and populations included in the meta-analysis are present in Table 1 . The relevant information for each RCT were collected, including authors, year, intervention and trial duration, as well as subjects' age, number, mean body weight, mean waist circumference, mean BMI, mean SBP and mean LDL-C.

\section{Cardiovascular outcomes}

A subgroup analysis was performed for weight, LDL-C and CRP based on the positive results measured by $95 \%$ CIs. The results showed a significant decrease in body weight $\left(\mathrm{MD}=-0.5,95 \% \mathrm{CI}[-0.74,-0.25], \mathrm{I}^{2}=35, P<\right.$ 


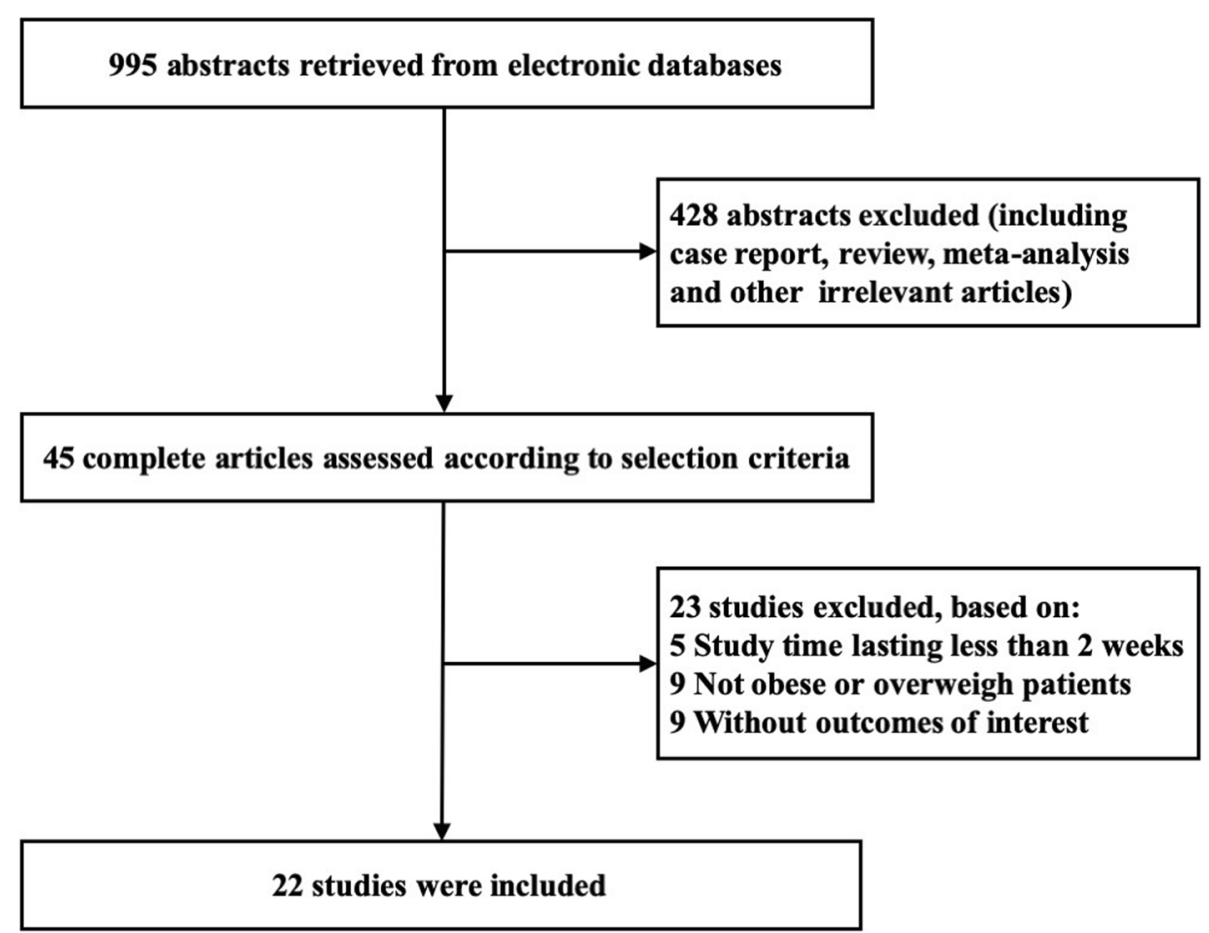

Fig. 1 Flow diagram of study inclusion and exclusion criteria

0.0001) and CRP (MD $=-0.36,95 \%$ CI $[-0.54,-0.18]$, $\left.\mathrm{I}^{2}=69 \%, P<0.0001\right)$ in the whole grain group, compared with the control group (Figs 2, 3). However, there were no significant differences between the two groups with regard to LDL-C $\left(\mathrm{MD}=-0.08,95 \% \mathrm{CI}[-0.16,0.00], \mathrm{I}^{2}=\right.$ $27 \%, P=0.05)$, waist circumference $(\mathrm{MD}=-0.12,95 \% \mathrm{CI}$ $\left.[-0.92,0.68], \mathrm{I}^{2}=44 \%, P=0.76\right), \mathrm{SBP}(\mathrm{MD}=-0.11,95 \%$ CI $\left.[-1.55,1.33], \mathrm{I}^{2}=3 \%, P=0.88\right)$, diastolic blood pressure $(\mathrm{DBP})\left(\mathrm{MD}=-0.44,95 \% \mathrm{CI}[-1.44,0.57], \mathrm{I}^{2}=15 \%\right.$, $P=0.39)$, and fasting glucose levels (MD $=-0.05,95 \% \mathrm{CI}$ $[-0.12,0.01], \mathrm{I}^{2}=31 \%, P=0.11$ ) (Figs. 4, 5, 6, 7 and 8 ).

\section{Assessment of bias}

Risk of bias in the included studies was assessed using Revman (Fig. 9). Some studies had high performance bias because they failed to implement blind intervention on subjects due to dietary intervention. However, no other significant sources of bias were observed.

\section{Discussion}

To our knowledge, this meta-analysis is the first to evaluate the impact of whole grain diet on cardiovascular risk factors in obese/overweight adults. Our analysis suggests that whole grain diet is associated with a decrease in body weight and CRP, compared with the control group, with no significant differences between the two groups in LDL-C, waist circumference, SBP, DBP and fasting glucose levels. This meta-analysis supports previous studies recommending whole grain diet for CVD patients.

CVD remain the leading cause of mortality worldwide, and obesity is a main risk factor for the pandemic of CVD. Slavin et al. reported the protective mechanisms of whole grain diet in CVD [46], including antioxidant effects and alteration of gut environment by dietary fibers, carbohydrates and short-chain fatty acid, but also by regulating glucose metabolism and response to insulin. By revealing these mechanisms, whole grains consumption was recommended in the Australia dietary guidelines in 2003 [47]. In the 2013 edition, the guidelines highlighted that at least 4 to 6 serves per day of grains food, mainly whole grains, is recommended for adults, especially for people with high risk of CVD and obesity [48]. In our systematic review, we assumed that obese patients receiving whole grain diet intervention would have lower CVD risk factors, such as body weight, LDL-C concentration, SBP, waist circumference, CRP, insulin resistance index and BMI. However, we only observed a slight reduction in body weight and LDL-C concentration in subjects on whole grains diet, compared with the control group. In addition, subjects on whole grains diet also had a greater reduction in CRP, although the heterogeneity among the studies was relatively large.

In order to investigate the source of heterogeneity, subgroup analysis was conducted for three outcomes using the positive results. For weight and LDL-C data, the subgroup whose participants had another chronic disease besides 
Table 1 Main characteristics of included studies. RCT, randomized controlled trial; BMI, body mass index; SBP, systolic blood pressure; LDL, low density lipoprotein; NA, not available

\begin{tabular}{|c|c|c|c|c|c|c|c|c|c|c|}
\hline Author, Year & $\begin{array}{l}\text { Study } \\
\text { design }\end{array}$ & Intervention & $\begin{array}{l}\text { Duration } \\
\text { of trial } \\
\text { (week) }\end{array}$ & Number & Age & $\begin{array}{l}\text { Mean } \\
\text { Body } \\
\text { weight } \\
(\mathrm{kg})\end{array}$ & $\begin{array}{l}\text { Mean Waist } \\
\text { circumference } \\
(\mathrm{cm})\end{array}$ & $\begin{array}{l}\text { Mean } \\
\text { BMl }(k g \\
\left.m^{2}\right)\end{array}$ & $\begin{array}{l}\text { Mean SBP } \\
(\mathrm{mmHg})\end{array}$ & $\begin{array}{l}\text { Mean } \\
\text { LDL } \\
\text { (mmol, } \\
\text { L) }\end{array}$ \\
\hline Katcher, 2008 [25] & $\mathrm{RCT}$ & Whole grain & 12 & 50 & NA & $\begin{array}{l}103.1 \text { vs } \\
106.2\end{array}$ & 82 vs 83.2 & $\mathrm{NA}$ & 123 vs 130 & $\begin{array}{l}2.83 \text { vs } \\
2.93\end{array}$ \\
\hline K. Rave, 2007 [26] & $\mathrm{RCT}$ & Whole grain & 4 & NA & NA & $\begin{array}{l}97.5 \text { vs } \\
98.8\end{array}$ & NA & $\begin{array}{l}33.2 \text { vs } \\
33.7\end{array}$ & 131 vs 134 & $\begin{array}{l}3.8 \text { vs } \\
3.8\end{array}$ \\
\hline $\begin{array}{l}\text { HARRIS JACKSON, } \\
2014 \text { [27] }\end{array}$ & $\mathrm{RCT}$ & Whole grain & 12 & 25 VS 25 & 45.8 vs 46.4 & $\begin{array}{l}99.5 \text { vs } \\
99.7\end{array}$ & NA & $\begin{array}{l}33.5 \text { vs } \\
32.9\end{array}$ & NA & NA \\
\hline $\begin{array}{l}\text { Maria Lankinen, } \\
2014 \text { [28] }\end{array}$ & $\mathrm{RCT}$ & Whole grain & 12 & 34 Vs 35 & NA & NA & 106.3 vs 105.8 & $\begin{array}{l}31.4 \text { vs } \\
31\end{array}$ & 135 vs 139 & $\begin{array}{l}3.2 \text { vs } \\
3.4\end{array}$ \\
\hline $\begin{array}{l}\text { Roager HM, } 2017 \\
\text { [29] }\end{array}$ & $\mathrm{RCT}$ & Whole grain & 8 & 50 Vs 50 & NA & $\begin{array}{l}85.4 \text { vs } \\
86.1\end{array}$ & 100.1 vs 100.4 & NA & 126.2 vs 124.2 & $\begin{array}{l}3.2 \text { vs } \\
3.2\end{array}$ \\
\hline Kirwan, 2016 [30] & $\mathrm{RCT}$ & Whole grain & 8 & 33 Vs 33 & NA & $\begin{array}{l}93.2 \text { vs } \\
93.7\end{array}$ & 96.4 vs 95.5 & $\begin{array}{l}32.9 \text { vs } \\
33.1\end{array}$ & NA & $\begin{array}{l}2.76 \text { vs } \\
2.76\end{array}$ \\
\hline $\begin{array}{l}\text { I.A.Brownlee, } 2010 \\
\text { [31] }\end{array}$ & $\mathrm{RCT}$ & Whole grain & 16 & 33 VS 33 & 45.9 vs 45.6 & $\begin{array}{l}86.7 \text { vs } \\
86.7\end{array}$ & NA & 30 vs 30 & 125.5 vs 127.3 & $\begin{array}{l}3.2 \text { vs } \\
3.2\end{array}$ \\
\hline $\begin{array}{l}\text { Steven K. Malin, } \\
2018 \text { [32] }\end{array}$ & $\mathrm{RCT}$ & Whole grain & 8 & 14 VS 14 & 37.9 vs 37.9 & $\begin{array}{l}97.9 \text { vs } \\
97.9\end{array}$ & NA & $\begin{array}{l}33.8 \text { vs } \\
33.9\end{array}$ & NA & NA \\
\hline $\begin{array}{l}\text { SCHUTTE, } 2018 \\
\text { [33] }\end{array}$ & $\mathrm{RCT}$ & Whole grain & 12 & 25 vs 25 & 61 vs 61 & $\begin{array}{l}84.6 \text { vs } \\
86.2\end{array}$ & 102.2 vs 103.4 & $\begin{array}{l}27.6 \text { vs } \\
28\end{array}$ & NA & NA \\
\hline $\begin{array}{l}\text { Bernard J. Venn, } \\
2010 \text { [34] }\end{array}$ & $\mathrm{RCT}$ & Whole grain & 72 & 53 vs 55 & 42 vs 42 & 99 vs 95 & NA & $\begin{array}{l}36.1 \text { vs } \\
34.7\end{array}$ & NA & NA \\
\hline $\begin{array}{l}\text { P. Hajihashemi, } \\
2014 \text { [35] }\end{array}$ & $\mathrm{RCT}$ & Whole grain & 6 & 44 vs 44 & 11.2 vs 11.2 & $\begin{array}{l}51.26 \text { vs } \\
51.26\end{array}$ & 80.69 vs 80.69 & $\begin{array}{l}23.57 \text { vs } \\
23.57\end{array}$ & NA & NA \\
\hline $\begin{array}{l}\text { K. Nelson, } 2016 \\
{[36]}\end{array}$ & $\mathrm{RCT}$ & Whole grain & 4 & 10 vs 10 & NA & NA & NA & $\begin{array}{l}30.77 \text { vs } \\
31\end{array}$ & 133.3 vs 132.1 & $\begin{array}{l}3.27 \text { vs } \\
3.12\end{array}$ \\
\hline $\begin{array}{l}\text { Paula Tighe, } 2013 \\
{[37]}\end{array}$ & RCT & Whole grain & 12 & 73 vs 63 & 51.6 vs 51.8 & NA & 85.7 vs 90.9 & 28 vs 28 & 125.9 vs 131.2 & $\begin{array}{l}3.45 \text { vs } \\
3.66\end{array}$ \\
\hline $\begin{array}{l}\text { Mette Kristensen, } \\
2017 \text { [38] }\end{array}$ & $\mathrm{RCT}$ & Whole grain & 12 & 30 vs 30 & NA & NA & NA & $\begin{array}{l}28.5 \text { vs } \\
28.4\end{array}$ & 130 vs 130 & $\begin{array}{l}3.7 \text { vs } \\
3.7\end{array}$ \\
\hline $\begin{array}{l}\text { S. FATAHI, } 2018 \\
\text { [39] }\end{array}$ & $\mathrm{RCT}$ & $\begin{array}{l}\text { Whole grain, } \\
\text { fruits and } \\
\text { vegetables, both }\end{array}$ & 10 & $\begin{array}{l}25 \text { vs } 25 \\
\text { vs } 25\end{array}$ & $\begin{array}{l}36.7 \text { vs } 34.6 \\
\text { vs } 39.9\end{array}$ & NA & NA & $\begin{array}{l}32.1 \text { vs } \\
32.3 \text { vs } \\
32.7\end{array}$ & NA & NA \\
\hline Xue Li, 2016 [40] & $\mathrm{RCT}$ & Whole grain & 4 & $\begin{array}{l}60 \text { vs } 79 \\
\text { vs } 80 \text { vs } \\
79\end{array}$ & $\begin{array}{l}59 \text { vs } 59.73 \\
\text { vs } 59.72 \text { vs } \\
59.44\end{array}$ & NA & NA & NA & $\begin{array}{l}143.7 \text { vs } 147.2 \\
\text { vs } 144.9 \text { vs } \\
147.1\end{array}$ & NA \\
\hline $\begin{array}{l}\text { Kevin C. Maki, } \\
2010 \text { [41] }\end{array}$ & RCT & Whole grain & 12 & 77 vs 67 & 50.1 vs 47.5 & $\begin{array}{l}88.7 \text { vs } \\
87.6\end{array}$ & 104.5 vs 105.2 & $\begin{array}{l}32 \text { vs } \\
32.2\end{array}$ & NA & 4 vs 3.99 \\
\hline $\begin{array}{l}\text { V. D. F. de Mello, } \\
2011 \text { [42] }\end{array}$ & $\mathrm{RCT}$ & $\begin{array}{l}\text { Whole grain, } \\
\text { Healthy diet }\end{array}$ & 12 & $\begin{array}{l}34 \text { vs } 36 \\
\text { vs } 34\end{array}$ & $\begin{array}{l}58 \text { vs } 59 \text { vs } \\
59\end{array}$ & $\begin{array}{l}89.2 \text { vs } \\
89.8 \text { vs } \\
89.5\end{array}$ & $\begin{array}{l}106.3 \text { vs } 105.7 \\
\text { vs } 105.7\end{array}$ & $\begin{array}{l}31.4 \text { vs } \\
31.1 \text { vs } \\
30.9\end{array}$ & $\begin{array}{l}135 \text { vs } 138 \text { vs } \\
139\end{array}$ & $\begin{array}{l}3.2 \text { vs } \\
3.1 \text { vs } \\
3.4\end{array}$ \\
\hline $\begin{array}{l}\text { A. } \\
\text { Stefoskaneedham, } \\
2017 \text { [43] }\end{array}$ & $\mathrm{RCT}$ & Whole grain & 12 & 30 vs 30 & 48.1 vs 48.6 & $\begin{array}{l}87.1 \text { vs } \\
86.1\end{array}$ & 102.5 vs 105.3 & $\begin{array}{l}31.2 \text { vs } \\
31.6\end{array}$ & 122.3 vs 126.2 & $\begin{array}{l}3.2 \text { vs } \\
3.5\end{array}$ \\
\hline $\begin{array}{l}\text { Kristensen, } 2012 \\
\text { [44] }\end{array}$ & $\mathrm{RCT}$ & Whole grain & 12 & 38 vs 34 & NA & $\begin{array}{l}81.3 \text { vs } \\
83.5\end{array}$ & 97.3 vs 99 & $\begin{array}{l}30 \text { vs } \\
30.4\end{array}$ & 133 vs 138 & $\begin{array}{l}3.75 \text { vs } \\
3.75\end{array}$ \\
\hline J. Tovar, 2014 [45] & $\mathrm{RCT}$ & Whole grain & 4 & 26 vs 26 & NA & NA & NA & NA & NA & NA \\
\hline $\begin{array}{l}\text { Mette Kristensen, } \\
2017 \text { [38] }\end{array}$ & $\mathrm{RCT}$ & Whole grain & 12 & 81 vs 88 & 36.2 vs 35.3 & $\begin{array}{l}80.2 \text { vs } \\
81.5\end{array}$ & NA & $\begin{array}{l}30.2 \text { vs } \\
30.1\end{array}$ & 109.8 vs 111.2 & $\begin{array}{l}2.9 \text { vs } \\
2.72\end{array}$ \\
\hline
\end{tabular}




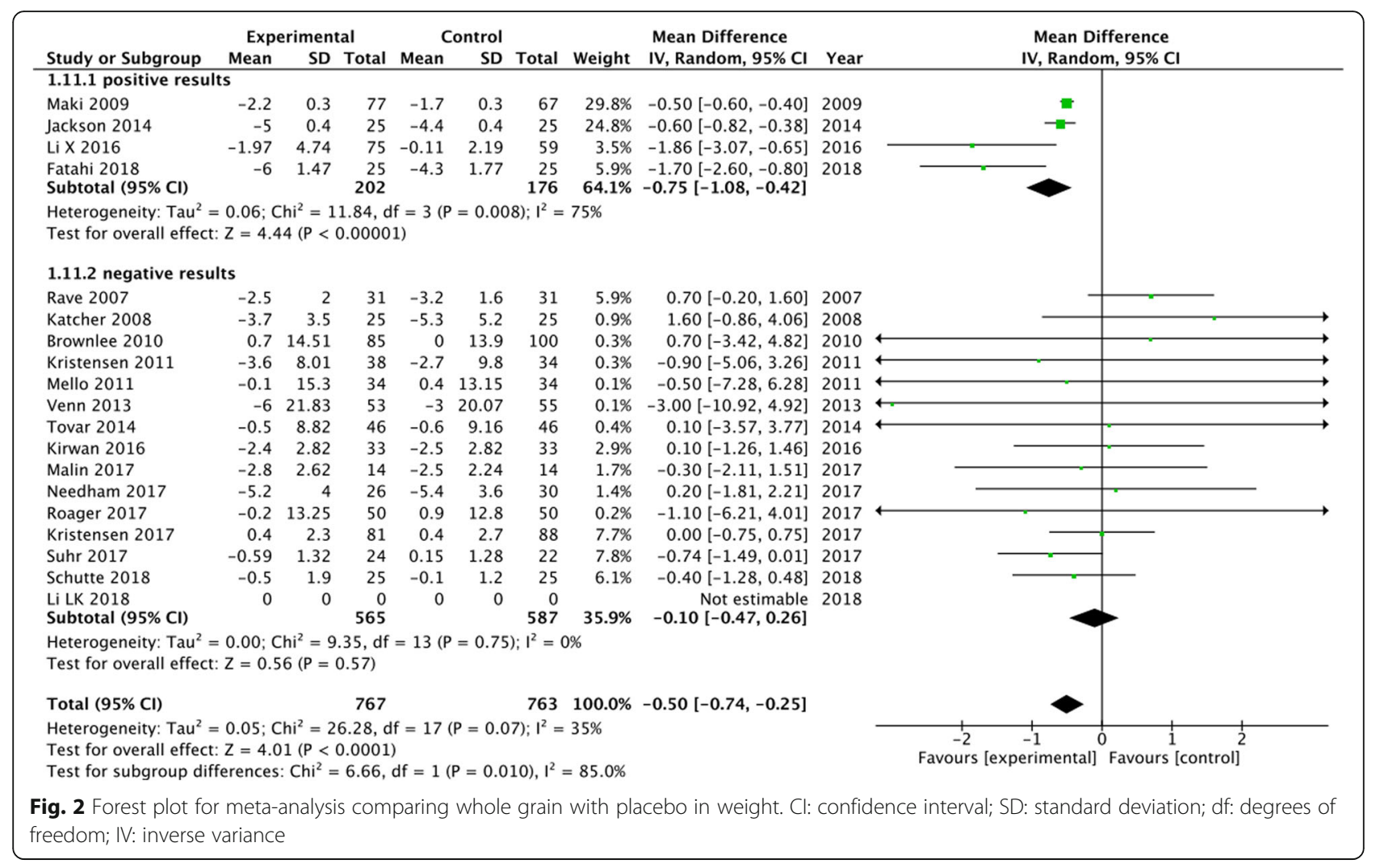

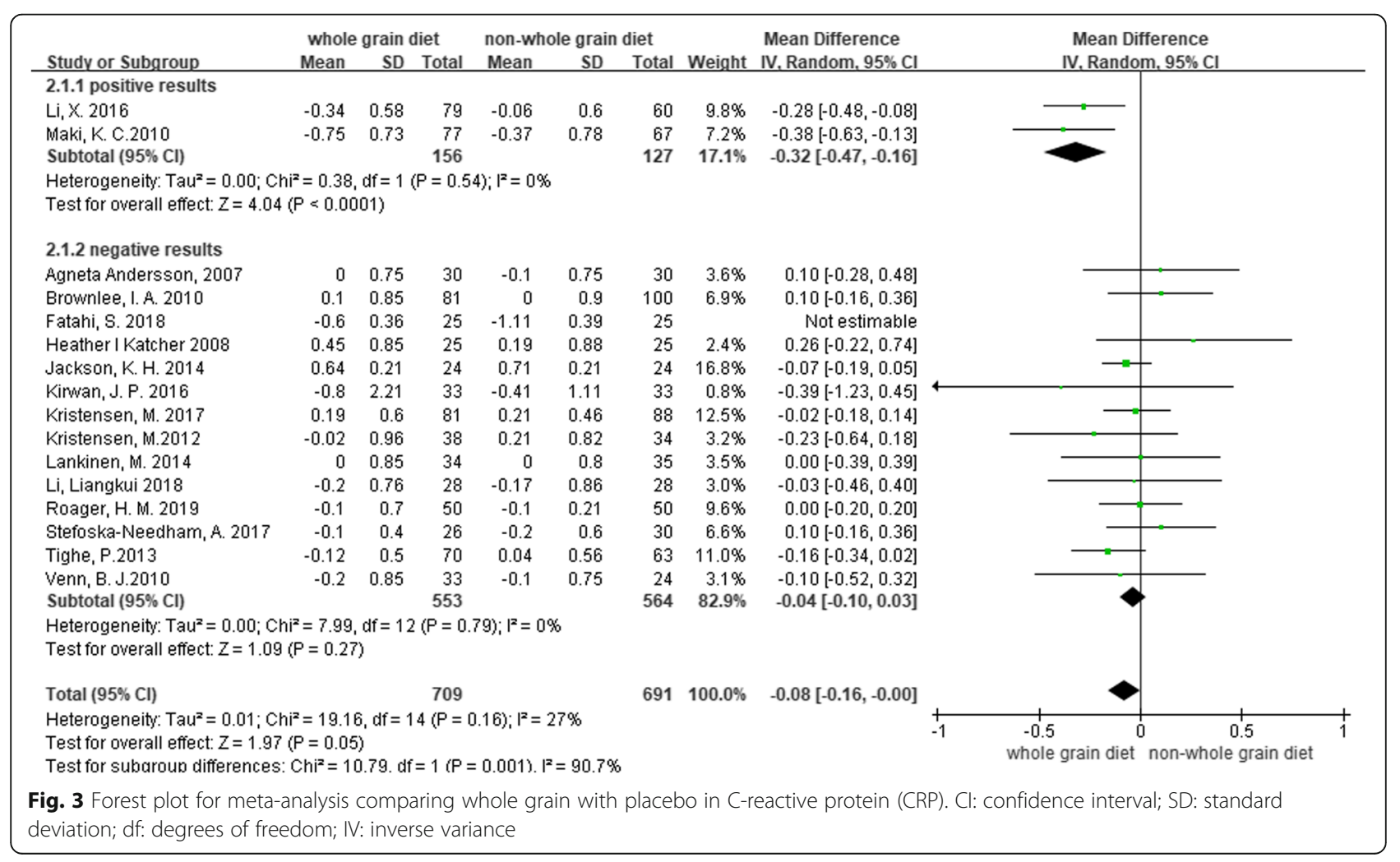




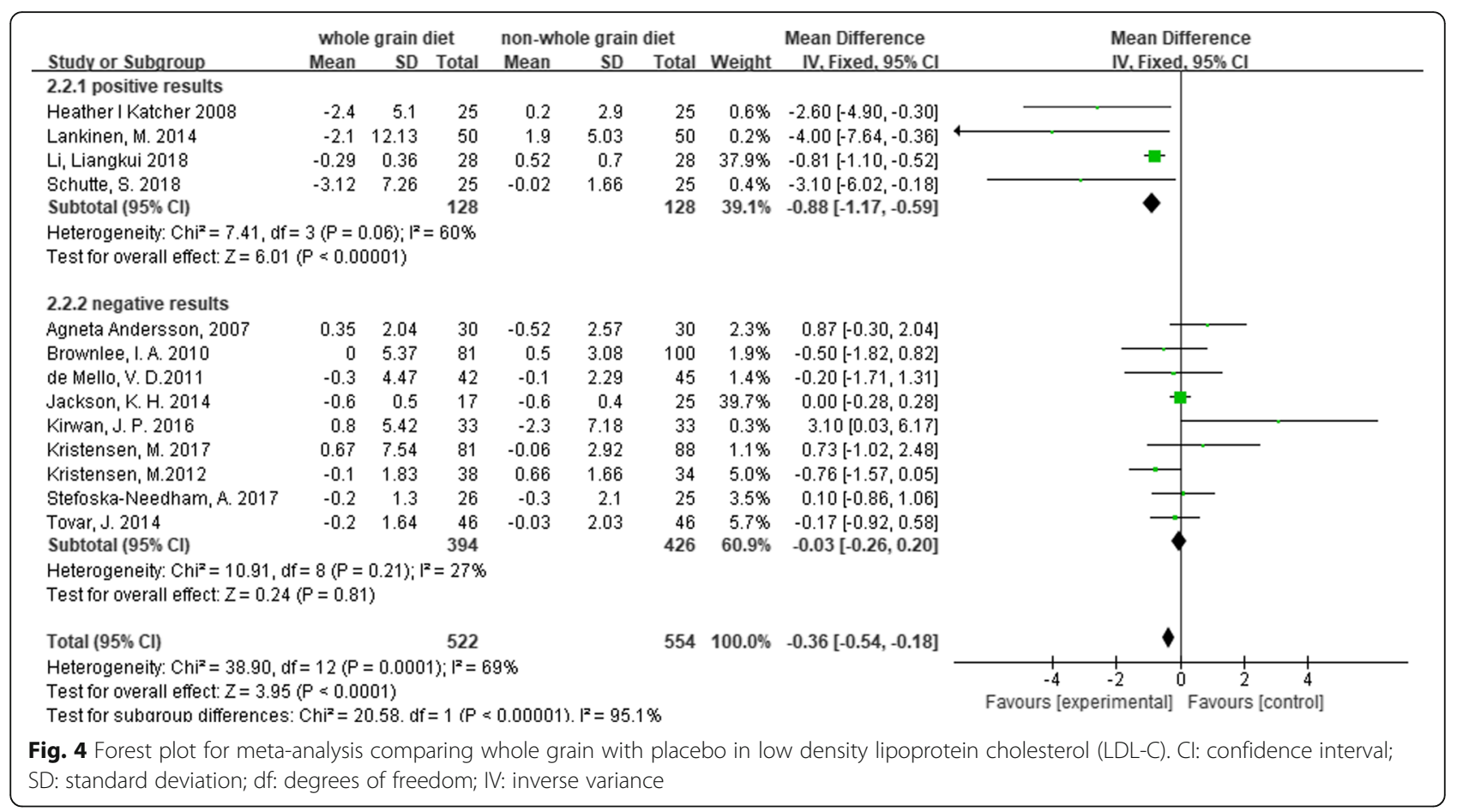

obesity, such as type 2 diabetes, abnormal plasma cholesterol, showed more significant results. Specially, these comorbidities are in accordance with the diagnosis criteria of metabolic syndrome (MetS). As defined by the United States National Heart, Lung and Blood Institute and by the American Heart Association Consensus Statement, MetS can be diagnosed when a patient has at least 3 of the 4 risk factors, which include abdominal obesity [waist circumference $>$ $102 \mathrm{~cm}$ for men, or $>88 \mathrm{~cm}$ for women], high triglycerides ( $\geq 150 \mathrm{mg} / \mathrm{dL}$ ), high-density lipoprotein cholesterol (HDL-C) [fasting serum HDL-C $<35 \mathrm{mg} / \mathrm{dL}$ for men, or $<39 \mathrm{mg} / \mathrm{dL}$ for women], high blood pressure [BP $\geq 130 / \geq 85 \mathrm{mmHg}$, and elevated fasting blood glucose ( $\geq 100 \mathrm{mg} / \mathrm{dL})$ [49]. MetS was reported as an important contributor for CVD incidence and mortality, as well as for all-cause mortality. Previous studies have demonstrated that whole grains diet can greatly reverse the process of MetS, lower postprandial plasma insulin and cholesterol levels $[4,10,50,51]$. Our results were in line with these findings, but also showed that whole grains diet can exert more effects on patients with more than one chronic metabolic disorders.

Another factor that was highlighted by the subgroup analysis was well-organized study design. Indeed, studies with positive results in this review showed high quality

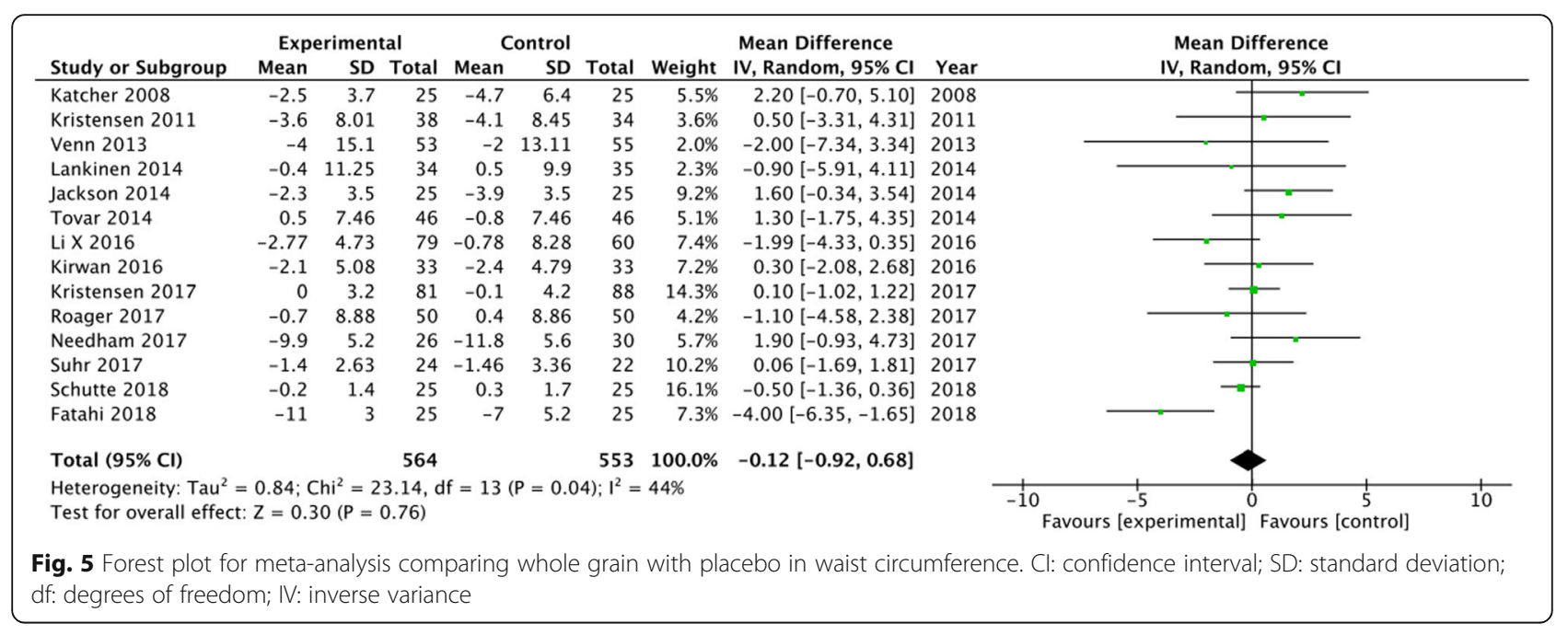




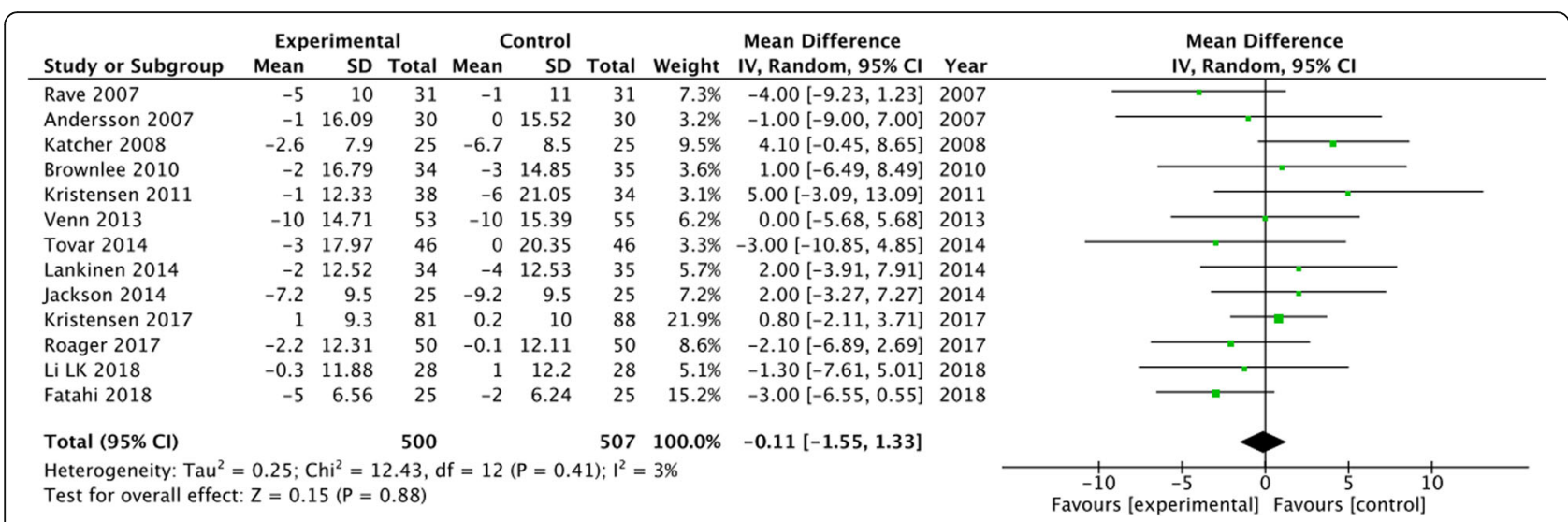

Fig. 6 Forest plot for meta-analysis comparing whole grain with placebo in systolic blood pressure. Cl: confidence interval; SD: standard deviation; df: degrees of freedom; IV: inverse variance

intervention monitoring. One effective method was "centralized intervention", which relies on giving educational lessons or standard 7-day cyclical menu before intervention period or during the visits $[25,40]$. Certain studies also supervised participants' diet by providing a 4-day diet record at each visit in a specific nutrition clinic, for which professional dieticians were recruited to assess these diet records and decide whether participants' diet should be adjusted according to the study design [28, 39]. Precise baseline information collection was also emphasized in these studies, which introduced a run-in period before the intervention period. In the run-in period, participants in both groups were asked to replace their habitual grain products with refined grains only to eliminate the habitual diet influence [28, 39]. In fact, structured run-in period was reported as an important element in clinical trial design, especially in medical studies and clinical trials. Runin strategy is usually used to diminish the effect of prior treatments, while it has no significant effect on realistic intervention outcomes [52, 53]. The duration of run-in period is still controversial, and this period was designed as 4 to 6 weeks, unequally, in our review.

Discrepancies among studies may also be caused by a variety of whole grains diet interventions. In our review, the diets included barley, oat, wheat, rye and quinoa, and few studies only gave ambiguous definitions. Previous studies showed differences when considering the type of whole grains diet. In a 6-week randomized trial, Suhr et al. reported that whole grain rye, but not wholegrain wheat, significantly lowered body weight and fat mass, compared with refined wheat [54]. In a meta-analysis, Li et al. investigated the effect of buckwheat on CVD risk factors in both human and animals. In human, buckwheat intervention significantly reduced glucose metabolism $(0.85 \mathrm{mmol} / \mathrm{L}, 95 \%$ $\mathrm{CI}[1.31,0.39])$, total cholesterol $(0.50 \mathrm{mmol} / \mathrm{L}, 95 \% \mathrm{CI}$ $[0.80,0.20])$ and triglycerides $(0.25 \mathrm{mmol} / \mathrm{L}, 95 \%$ CI $[0.49$, $0.02]$ ), compared with the control group. However, only triglycerides and total cholesterol showed slight differences in animals, with high heterogeneity [55]. On the other hand, another trial on quinoa suggested that quinoa consumption

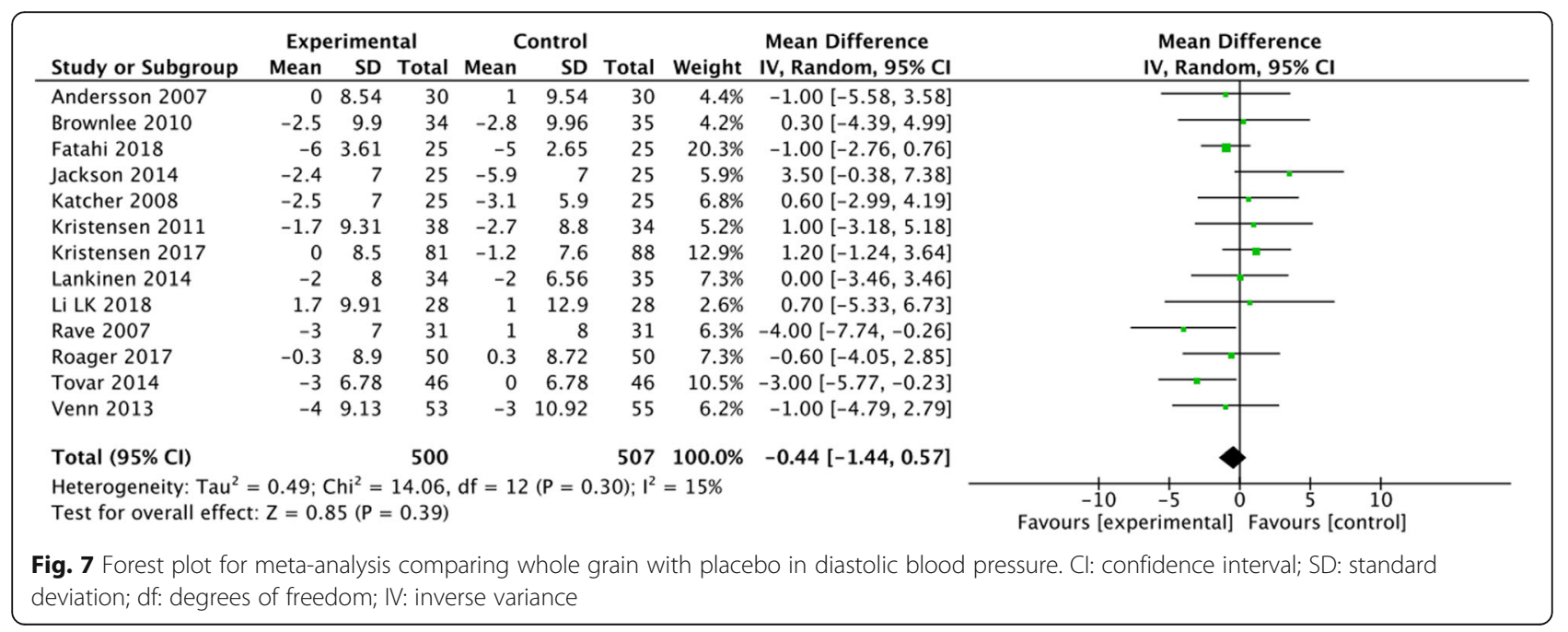




\begin{tabular}{|c|c|c|c|c|c|c|c|c|c|c|c|}
\hline \multirow[b]{2}{*}{ Study or Subgroup } & \multicolumn{3}{|c|}{ Experimental } & \multicolumn{3}{|c|}{ Control } & \multirow[b]{2}{*}{ Weight } & \multirow{2}{*}{$\begin{array}{l}\text { Mean Difference } \\
\text { IV, Random, 95\% CI }\end{array}$} & \multirow[b]{2}{*}{ Year } & \multirow{2}{*}{\multicolumn{2}{|c|}{$\begin{array}{c}\text { Mean Difference } \\
\text { IV, Random, } 95 \% \mathrm{Cl}\end{array}$}} \\
\hline & Mean & SD & Total & Mean & SD & Total & & & & & \\
\hline Rave 2007 & -0.4 & 0.3 & 31 & -0.5 & 0.5 & 31 & $6.9 \%$ & $0.10[-0.11,0.31]$ & 2007 & & \\
\hline Andersson 2007 & 0.1 & 0.8 & 30 & 0 & 0.85 & 30 & $2.3 \%$ & $0.10[-0.32,0.52]$ & 2007 & & \\
\hline Katcher 2008 & -0.07 & 0.26 & 25 & -0.08 & 0.37 & 25 & $8.2 \%$ & $0.01[-0.17,0.19]$ & 2008 & & \\
\hline Brownlee 2010 & -0.2 & 0.89 & 34 & 0 & 0.56 & 35 & $3.0 \%$ & $-0.20[-0.55,0.15]$ & 2010 & & \\
\hline Kristensen 2011 & -0.03 & 0.55 & 38 & -0.08 & 0.41 & 34 & $6.1 \%$ & $0.05[-0.17,0.27]$ & 2011 & & \\
\hline Venn 2013 & 0.2 & 0.6 & 53 & 0.2 & 0.46 & 55 & $7.0 \%$ & $0.00[-0.20,0.20]$ & 2013 & & \\
\hline Lankinen 2014 & 0 & 0.46 & 34 & 0 & 0.5 & 35 & $6.0 \%$ & $0.00[-0.23,0.23]$ & 2014 & & \\
\hline Jackson 2014 & -0.24 & 0.3 & 25 & -0.06 & 0.3 & 25 & $8.8 \%$ & $-0.18[-0.35,-0.01]$ & 2014 & & \\
\hline Tovar 2014 & 0.12 & 4.34 & 46 & -0.03 & 0.51 & 46 & $0.3 \%$ & $0.15[-1.11,1.41]$ & 2014 & & \\
\hline Kirwan 2016 & -0.17 & 0.65 & 33 & 0.07 & 0.54 & 33 & $4.2 \%$ & $-0.24[-0.53,0.05]$ & 2016 & $\leftarrow$ & \\
\hline Li X 2016 & -1.7 & 2.72 & 79 & -0.2 & 2.75 & 60 & $0.5 \%$ & $-1.50[-2.42,-0.58]$ & 2016 & 4 & \\
\hline Roager 2017 & -0.1 & 0.56 & 50 & 0 & 0.6 & 50 & $6.0 \%$ & $-0.10[-0.33,0.13]$ & 2017 & & \\
\hline Needham 2017 & -0.15 & 0.4 & 26 & -0.11 & 0.3 & 30 & $7.7 \%$ & $-0.04[-0.23,0.15]$ & 2017 & & \\
\hline Malin 2017 & -0.09 & 0.46 & 14 & -0.08 & 0.25 & 14 & $4.5 \%$ & $-0.01[-0.28,0.26]$ & 2017 & & \\
\hline Kristensen 2017 & -0.07 & 0.49 & 81 & -0.05 & 0.35 & 88 & $11.3 \%$ & $-0.02[-0.15,0.11]$ & 2017 & & \\
\hline Li LK 2018 & -0.26 & 0.66 & 28 & -0.07 & 0.55 & 28 & $3.6 \%$ & $-0.19[-0.51,0.13]$ & 2018 & & \\
\hline Schutte 2018 & 0.1 & 0.5 & 25 & 0 & 0.2 & 25 & $6.6 \%$ & $0.10[-0.11,0.31]$ & 2018 & & \\
\hline Fatahi 2018 & -0.72 & 0.42 & 25 & -0.5 & 0.29 & 25 & $7.1 \%$ & $-0.22[-0.42,-0.02]$ & 2018 & & \\
\hline Total $(95 \% \mathrm{Cl})$ & & & 677 & & & 669 & $100.0 \%$ & $-0.05[-0.12,0.01]$ & & & \\
\hline \multicolumn{10}{|c|}{$\begin{array}{l}\text { Heterogeneity: } \operatorname{Tau}^{2}=0.01 ; \mathrm{Chi}^{2}=24.50, \mathrm{df}=17(\mathrm{P}=0.11) ; \mathrm{I}^{2}=31 \% \\
\text { Test for overall effect: } \mathrm{Z}=1.58(\mathrm{P}=0.11)\end{array}$} & $\begin{array}{cc}-0.2 & -0.1 \\
\text { Favours [experimental] }\end{array}$ & 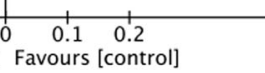 \\
\hline
\end{tabular}

can regulate glucose response, with only minimal effects on other CVD risk biomarkers [56]. As a result, the discrepancies among studies in this review could be related to different diets, and thus, further subgroup analysis should be conducted based on the type of whole grains diet.

Interestingly, we observed that only few studies investigated plasma alkylresorcinols as a biomarker to quantify the intake of whole grain diet, which can lead to more accurate measurement of the effectiveness of whole grains diet, especially for wheat, rye and barley [27, 33, 57]. Alkylresorcinols are a short-half-life phenolic lipid compounds that are abundant in the outer layer of whole wheat, rye and barley, and is homologues with oddnumbered hydrocarbon side chains $[57,58]$. Although its

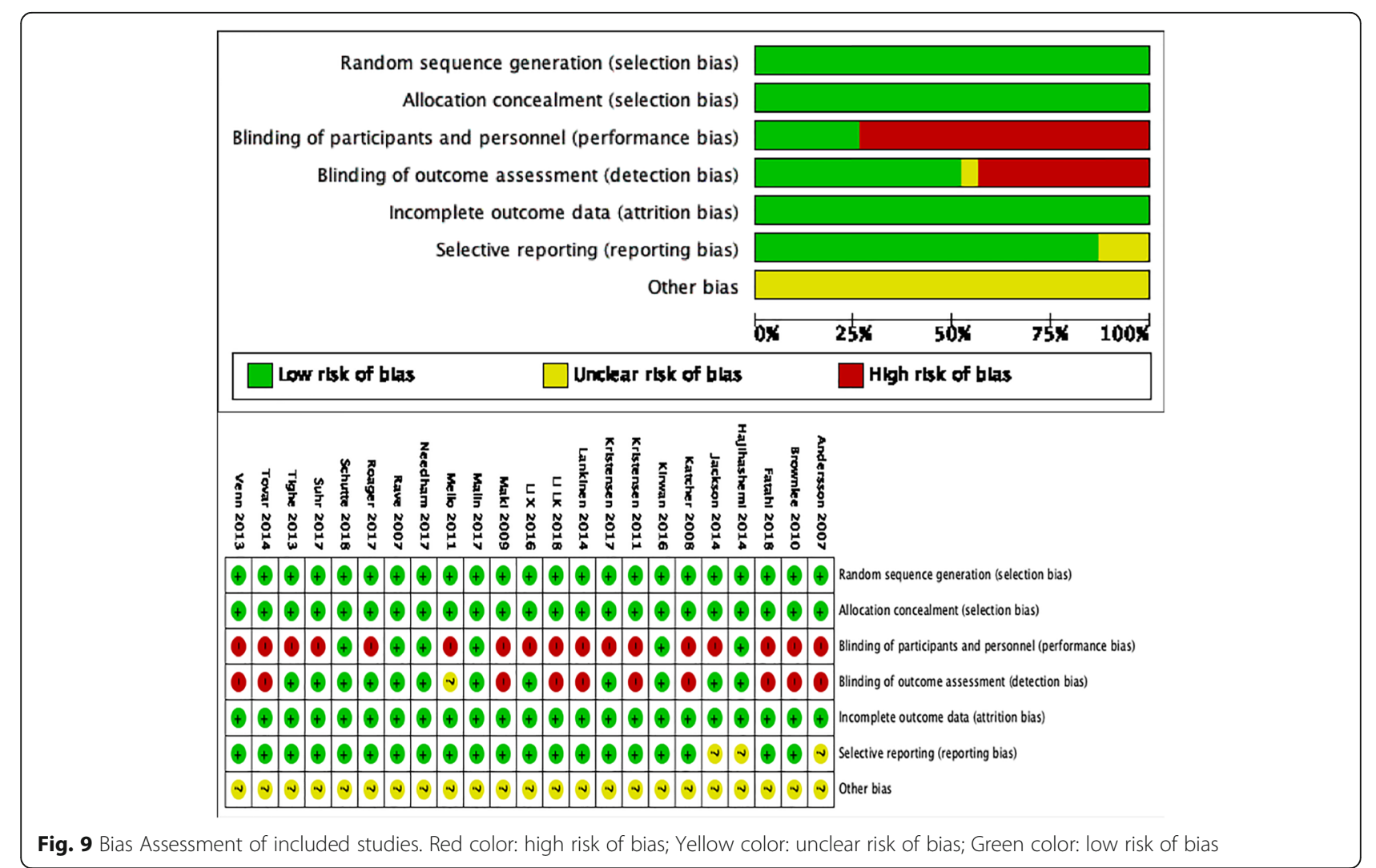


half-life is estimated to be around $5 \mathrm{~h}$, single plasma alkylresorcinols measurement has been shown to be a reliable biomarker for long-term whole grain food consumption [59]. The concentration of alkylresorcinol has been also reported as a sensitive indicator that is correlated with whole grain intake, and it could be used to distinguish between low- and high- whole grain consumers. Besides, it was suggested that there is no difference if the alkylresorcinol concentration is expressed by " $\mathrm{nmol} / \mathrm{mmol}$ total lipids" or "nmol/L", which indicates that the concentration of alkylresorcinol is not influenced by lipid distribution [60]. In summary, the concentration of alkylresorcinol should be used as a reliable biomarker for evaluating the true effect of whole grain diet in future studies.

There are some limitations about in this study that are worth to mention. First, only 22 studies including 1865 subjects met our inclusion criteria. Hence, the issue of bias and heterogeneity might not be fully investigated using such as relatively small sample size. Second, some of the included RCTs lacked baseline information and/ or outcome data for the comprehensive meta-analysis. Third, the difference in the composition of whole grains in each article may cause deviations in the results. Therefore, the outcomes and overall conclusions should be interpreted with these limitations in mind.

\section{Conclusion}

In conclusion, our study demonstrated that whole grain food can slightly reduce body weight and CRP in obese populations, compared with non-whole grain diet, with not significant effect on other CVD risk factors. This effect was more likely in patients with other chronic metabolic disorders besides obesity. The discrepancies among studies can be explained by the different monitoring approaches and by the types of diets used. To adjust for the effectiveness among diverse types of whole grain diets, plasma alkylresorcinol concentration can be used in future studies as a biomarker to reflect the level of whole grains intake. In addition, further studies should be conducted on more specific subgroups of patients.

\section{Abbreviations}

BMI: Body mass index; BP: Blood pressure; Cl: Confidence intervals; CRP: Creactive protein; CVD: Cardiovascular disease; DBP: Diastolic blood pressure; LDL-C: Low-density lipoprotein cholesterol; MD: Mean difference; MetS: Metabolic syndrome; OR: Odds ratios; PRISMA: Preferred reporting items for systematic reviews and Meta-analyses statement; RCTs: Randomized controlled trials; Revman: Review manager; SBP: Systolic blood pressure

\section{Acknowledgements}

Not applicable.

\section{Declarations}

Authors have no conflicts to declare.

\section{Authors' contributions}

WHW and JNL planned the study and searched the literature and selected the trials to be included. XXC entered the data to the RevMan program and carried out the statistical analysis. MY checked that the entered data were consistent with original reports. QP wrote the draft manuscript and LXG participated in the critical revision of the manuscript. All authors read and approved the final version for publication.

\section{Funding}

Sponsorship for this study and the article processing charges were funded by the National Natural Science Foundation of China (Grant No.81670763 and 81471050 ). They had no role in the design of the study and collection, analysis and interpretation of data and in writing the manuscript.

\section{Availability of data and materials}

The datasets used and/or analysed during the current study are available from the corresponding author on reasonable request.

Ethics approval and consent to participate

Ethical approval was not applicable for this systematic review and metaanalysis.

\section{Consent for publication}

Not applicable.

\section{Competing interests}

The authors declare that they have no competing interests.

\section{Author details}

${ }^{1}$ Department of Endocrinology, Beijing Hospital, National Center of Gerontology, Institute of Geriatric Medicine, Chinese Academy of Medical Sciences, Beijing, People's Republic of China. ${ }^{2}$ Department of Cardiology, Fuwai Hospital, National Center for Cardiovascular Diseases, Chinese Academy of Medical Sciences and Peking Union Medical College, Beijing, China.

Received: 14 August 2019 Accepted: 9 January 2020

Published online: 18 February 2020

\section{References}

1. WHO. World Health Statistics 2017: Monitoring Health for the SDGs. Available online: http://www.who.int/gho/publications/world health statistics.2017.en, (Accessed 5 June 2018).

2. Ogden C, Carroll M, Fryar C, Flegal K. Prevalence of obesity among adults and youth: United States, 2011-2014. NCHS data brief, no. 219. Hyattsville: National Center for Health Statistics; 2015

3. McKeown NM, Meigs JB, Liu S, Saltzman E, Wilson PW, Jacques PF. Carbohydrate nutrition, insulin resistance, and the prevalence of the metabolic syndrome in the Framingham offspring cohort. Diabetes Care. 2004;27:538-46.

4. Sahyoun NR, Jacques PF, Zhang XL, Juan W, McKeown NM. Whole-grain intake is inversely associated with the metabolic syndrome and mortality in older adults. Am J Clin Nutr. 2006;83:124-31.

5. Koh-Banerjee $P$, Rimm EB. Whole grain consumption and weight gain: a review of the epidemiological evidence, potential mechanisms and opportunities for future research. Proc Nutr Soc. 2003;62:25-9.

6. Liese AD, Roach AK, Sparks KC, Marquart L, D'Agostino RB Jr, Mayer-Davis EJ. Whole-grain intake and insulin sensitivity: the insulin resistance atherosclerosis study. Am J Clin Nutr. 2003;78:965-71.

7. Liu S, Willett WC, Manson JE, Hu FB, Rosner B, Colditz G. Relation between changes in intakes of dietary fiber and grain products and changes in weight and development of obesity among middle-aged women. Am J Clin Nutr. 2003:78:920-7.

8. Hartvigsen ML, Lærke HN, Overgaard A, et al. Postprandial effects of test meals including concentrated arabinoxylan and whole grain rye in subjects with the metabolic syndrome: a randomised study. Eur J Clin Nutr. 2014;68:567-74.

9. Pol K, Christensen R, Bartels EM, et al. Whole grain and body weight changes in apparently healthy adults: a systematic review and meta-analysis of randomized controlled studies. Am J Clin Nutr. 2013;98:872-84.

10. Magnusdottir OK, Landberg R, Gunnarsdottir I, et al. Whole grain rye intake, reflected by a biomarker, is associated with favorable blood lipid outcomes in subjects with the metabolic syndrome-a randomized study. PLoS One. 2014;9:e110827. 
11. Montonen J, Boeing $H$, Fritsche $A$, et al. Consumption of red meat and whole-grain bread in relation to biomarkers of obesity, inflammation, glucose metabolism and oxidative stress. Eur J Nutr. 2013;52:337-45.

12. Slavin JL, Martini MC, Jacobs DR Jr, Marquart L. Plausible mechanisms for the protectiveness of whole grains. Am J Clin Nutr. 1999;70(suppl):459S-63S

13. Slavin J. Why whole grains are protective: biological mechanisms. Proc Nutr Soc. 2003;62:129-34.

14. Rosen LA, Ostman EM, Bjorck IM. Effects of cereal breakfasts on postprandial glucose, appetite regulation and voluntary energy intake at a subsequent standardized lunch; focusing on rye products. Nutr J. 2011;10:7.

15. Hartvigsen ML, Gregersen S, Laerke HN, Holst JJ, Bach Knudsen KE, Hermansen K. Effects of concentrated arabinoxylan and beta-glucan compared with refined wheat and whole grain rye on glucose and appetite in subjects with the meta- bolic syndrome: a randomized study. Eur J Clin Nutr. 2014;68:84-90.

16. Forsberg $T$, Aman $P$, Landberg R. Effects of whole grain rye crisp bread for breakfast on appetite and energy intake in a subsequent meal: two randomised controlled trials with different amounts of test foods and breakfast energy con- tent. Nutr J. 2014;13:26.

17. Kristensen M, Jensen MG, Riboldi G, Petronio M, Bügel S, Toubro S, et al. Whole- grain vs. refined wheat bread and pasta. Effect on postprandial glycemia, appetite, and subsequent ad libitum energy intake in young healthy adults. Appetite. 2010;54:163-9.

18. Isaksson H, Tillander I, Andersson R, Olsson J, Fredriksson H, Webb DL, et al. Whole grain rye breakfast - sustained satiety during three weeks of regular consumption. Physiol Behav. 2012;105:877-84.

19. Hebowicz J, Lindstedt S, Bjorgell O, Hoglund P, Almer LO, Darwiche G. The botanical integrity of wheat products influences the gastric distention and satiety in healthy subjects. Nutr J. 2008;7:12.

20. Lutsey PL, Jacobs DR Jr, Kori S, Mayer-Davis E, Shea S, Steffen LM, et al. Whole grain intake and its cross-sectional association with obesity, insulin resistance, inflammation, diabetes and subclinical CVD: the MESA study. Br J Nutr. 2007;98:397-405.

21. McKeown NM, Meigs JB, Liu S, Wilson PW, Jacques PF. Whole-grain intake is favorably associated with metabolic risk factors for type 2 diabetes and cardiovascular disease in the Framingham offspring study. Am J Clin Nutr. 2002;76:390-8

22. Koh-Banerjee P, Franz M, Sampson L, Liu S, Jacobs DR Jr, Spiegelman D, et al. Changes in whole-grain, bran, and cereal fiber consumption in relation to 8-y weight gain among men. Am J Clin Nutr. 2004;80:1237-45.

23. Bazzano LA, Song Y, Bubes V, Good CK, Manson JE, Liu S. Dietary intake of whole and refined grain breakfast cereals and weight gain in men. Obes Res. 2005;13:1952-60.

24. Thielecke F, Jonnalagadda SS. Can whole grain help in weight management? J Clin Gastroenterol. 2014;48:S70-S7.

25. Katcher HI, Legro RS, Kunselman AR, et al. The effects of a whole grainenriched hypocaloric diet on cardiovascular disease risk factors in men and women with metabolic syndrome. Am J Clin Nutr. 2008;87(1):79-90.

26. Rave K, Roggen K, Dellweg S, Heise T, Dieck H. Improvement of insulin resistance after diet with a whole-grain based dietary product: results of a randomized, controlled cross-over study in obese subjects with elevated fasting blood glucose. 2007:49:929-36.

27. Jackson KH, West SG, Vanden Heuvel JP, et al. Effects of whole and refined grains in a weight-loss diet on markers of metabolic syndrome in individuals with increased waist circumference: a randomized controlledfeeding trial. Am J Clin Nutr. 2014;100(2):577-86

28. Lankinen $M$, Kolehmainen $M$, Jääskeläinen $T$, et al. Effects of whole grain, fish and bilberries on serum metabolic profile and lipid transfer protein activities: a randomized trial (Sysdimet). PLoS One. 2014;9(2):1-12.

29. Roager HM, et al. Whole grain-rich diet reduces body weight and systemic low-grade inflammation without inducing major changes of the gut microbiome: a randomised cross-over trial. Gut. 2017:0:1-11.

30. Kirwan JP, et al. A whole-grain diet reduces cardiovascular risk factors in overweight and obese adults : a randomized controlled trial 1 - 3. 2016:1-8. https://doi.org/10.3945/jn.116.230508.1.

31. Brownlee $I A$, et al. Markers of cardiovascular risk are not changed by increased whole-grain intake : the WHOLEheart study, a randomised, controlled dietary intervention. 2010:125-34. https://doi.org/10.1017/ S0007114510000644.

32. Malin SK, et al. A whole-grain diet reduces peripheral insulin resistance and improves glucose kinetics in obese adults : A randomized-controlled trial. Metabolism. 2018;82:111-7.
33. Schutte S, Esser D, Hoevenaars FPM, et al. A 12-wk whole-grain wheat intervention protects against hepatic fat: the Graandioos study, a randomized trial in overweight subjects. Am J Clin Nutr. 2018;108(6):1264-74.

34. Venn BJ, et al. The effect of increasing consumption of pulses and wholegrains in obese people: a randomized controlled trial. J Am Coll Nutr. 2010:37-41. https://doi.org/10.1080/07315724.2010.10719853.

35. Hajihashemi P, Azadbakht L, Hashemipor M, Kelishadi R, Esmaillzadeh A. Whole-grain intake favorably affects markers of systemic inflammation in obese children : A randomized controlled crossover clinical trial. 2014:13018. https://doi.org/10.1002/mnfr.201300582.

36. Nelson $\mathrm{K}$, et al. Effects of malted and non-malted whole-grain wheat on metabolic and inflammatory biomarkers in overweight / obese adults : A randomised crossover pilot study. FOOD Chem. 2016;194:495-502.

37. Tighe $P$, et al. Effects of wheat and oat-based whole grain foods on serum lipoprotein size and distribution in overweight middle aged people: a randomised controlled trial. 2013;8.

38. Kristensen M, Pelletier $X$, Ross AB, Thielecke F. A high rate of noncompliance confounds the study of whole grains and weight maintenance in a randomised intervention trial-the case for greater use of dietary biomarkers in nutrition intervention studies. Nutrients. 2017;9.

39. Fatahi S, Daneshzad E, Kord-Varkaneh $\mathrm{H}$, et al. Impact of diets rich in whole grains and fruits and vegetables on cardiovascular risk factors in overweight and obese women: a randomized clinical feeding trial. J Am Coll Nutr. 2018; 37(7):568-77.

40. Li X, Cai X, Ma X, et al. Short-and long-term effects of wholegrain oat intake on weight management and glucolipid metabolism in overweight type-2 diabetics: a randomized control trial. Nutrients. 2016;8(9):1-14.

41. Maki KC, et al. Whole-grain ready-to-eat oat cereal, as part of a dietary program for weight loss, reduces low-density lipoprotein cholesterol in adults with overweight and obesity more than a dietary program including low-fiber control foods. YJADA. 2010;110:205-14.

42. De Mello VDF, Schwab U, Kolehmainen M. A diet high in fatty fish bilberries and wholegrain products improves markers of endothelial function and inflammation in individuals with impaired glucose metabolism in a randomised controlled trial: The Sysdimet study. 2011:2755-67. https:// doi.org/10.1007/s00125-011-2285-3.

43. Stefoska-Needham A, et al. A diet enriched with red sorghum flaked biscuits, compared to a diet containing white wheat flaked biscuits, does not enhance the effectiveness of an energy-restricted meal plan in overweight and mildly obese adults. J Am Coll Nutr. 2017;36:184-92.

44. Kristensen $\mathrm{M}$, et al. Whole grain compared with refined wheat decreases the percentage of body fat following a 12-week, energy-restricted dietary intervention in postmenopausal women. J Nutr. 2012;142:710-6.

45. Tovar J, Nilsson A, Johansson M, Bjo I. Combining functional features of whole-grain barley and legumes for dietary reduction of cardiometabolic risk: a randomised cross-over intervention in mature women. 2014;1:706-14.

46. Slavin J. Why whole grains are protective: biological mechanisms. Proc Nutr Soc. 2019;62:129-34

47. National Health and Medical Research Council. Dietary Guidelines for Children and Adolescents in Australia. Canberra: Commonwealth of Australia; 2003a.

48. Odphp. 2015-2020 Dietary Guidelines for Americans. 2015. Available from: http://health.gov/dietaryguidelines/2015/guidelines/.

49. Sherling $\mathrm{DH}$, Perumareddi $\mathrm{P}$, Hennekens $\mathrm{CH}$, Schmidt CE. Metabolic syndrome: clinical and policy implications of the new silent killer. J Cardiovasc Pharmacol Ther. 2017;22(4):365-7.

50. Giacco R, Costabile G, Della Pepa G, et al. A whole-grain cereal-based diet lowers postprandial plasma insulin and triglyceride levels in individuals with metabolic syndrome. Nutr Metab Cardiovasc Dis. 2014;24:837-44.

51. Vetrani CR, Costabile G, Luongo D, et al. Effects of whole-grain cereal foods on plasma short chain fatty acid concentrations in individuals with the metabolic syndrome. Nutrition. 2016;32:217-21.

52. Packer M. Why has a run-in period been a design element in most landmark clinical trials? Analysis of the critical role of run-in periods in drug development. J Card Fail. 2017;23(9):697-9.

53. Schechtman KB, Louis S. Run-in periods in randomized clinical trials. J Card Fail. 2017;23:700-1.

54. Suhr J, Vuholm S, Iversen KN, et al. Wholegrain rye, but not wholegrain wheat, lowers body weight and fat mass compared with refined wheat: a 6-week randomized study. Eur J Clin Nutr. 2017;71(8):959-67.

55. Li L, Lietz G, Seal C. Buckwheat and CVD risk markers: A systematic review and meta-analysis. Nutrients. 2018;10(5):E619. 
56. Li L, Lietz G, Bal W, et al. Effects of quinoa (Chenopodium quinoa Willd.) consumption on markers of CVD risk. Nutrients. 2018;10(6):1-17.

57. Landberg R, Kamal-Eldin A, Andersson A, et al. Alkylresorcinols as biomarkers of whole-grain wheat and rye intake: plasma concentration and intake estimated from dietary records. Am J Clin Nutr. 2008;87:832-8.

58. Landberg R, Linko A-M, Kamal-Eldin A, et al. The journal of nutrition nutrient physiology, metabolism, and nutrient-nutrient interactions human plasma kinetics and relative bioavailability of Alkylresorcinols after intake of Rye bran. J Nutr. 2006;136:2760-5.

59. Landberg R, Åman P, Hallmans G, Johansson I. Long-term reproducibility of plasma alkylresorcinols as biomarkers of whole-grain wheat and rye intake within northern Sweden health and disease study cohort. Eur J Clin Nutr. 2013:67:259-63.

60. Ross AB, Bourgeois A, Ndung'u Macharia $H$, et al. Plasma alkylresorcinols as a biomarker of whole-grain food consumption in a large population: results from the WHOLEheart intervention study. Am J Clin Nutr. 2012;95:204-15.

\section{Publisher's Note}

Springer Nature remains neutral with regard to jurisdictional claims in published maps and institutional affiliations.

Ready to submit your research? Choose BMC and benefit from:

- fast, convenient online submission

- thorough peer review by experienced researchers in your field

- rapid publication on acceptance

- support for research data, including large and complex data types

- gold Open Access which fosters wider collaboration and increased citations

- maximum visibility for your research: over $100 \mathrm{M}$ website views per year

At BMC, research is always in progress.

Learn more biomedcentral.com/submissions 